FINAL VERSION: Carrero-Pazos, M., Espinosa-Espinosa, D. 2018. Tailoring 3D modelling techniques for epigraphic texts restitution. Case studies in deteriorated roman inscriptions. Digital Applications in Archaeology and Cultural Heritage, vol 10. e00079 https://doi.org/10.1016/j.daach.2018.e00079

\title{
Tailoring 3D Modelling Techniques for Epigraphic Texts Restitution. Case Studies in Deteriorated Roman Inscriptions
}

Miguel Carrero-Pazos; Corresponding author miguel.carrero.pazos@gmail.com

Department of History, University of Santiago de Compostela Praza da Universidade 1, 15782. Santiago de Compostela (Spain)

Orcid: 0000-0001-9203-9954

David Espinosa-Espinosa

davidespinosaespinosa@gmail.com

Department of History, University of Santiago de Compostela

Praza da Universidade 1, 15782. Santiago de Compostela (Spain)

Orcid: 0000-0002-2337-9047

\begin{abstract}
Digital Image Modelling is becoming a standard approach in epigraphic studies, mostly expressed in the diffusion practice of research groups which want their materials being publicly accessible. However, there is an important lack of works which seek for the use of $3 \mathrm{D}$ tools to improve the epigraphic analysis and text reading. Therefore, this paper attempts to show the application of Photogrammetry Structure from Motion and Digital Image Modelling to 3D record and analyse inscriptions that are in poor state of preservation, aiming to resolve some text-restitution problems and contribute towards the definition of new methodologies in Roman epigraphy.
\end{abstract}

Keywords: 3D modelling; Photogrammetry SfM; MeshLab; Roman Epigraphy; Gallaecia

\section{Introduction}

The expansion of 3D modelling throughout the Humanities has contributed to the opening of new methodological approaches, such as the reconstruction and virtual representation of archaeological sites or objects (Babeu 2011). This is particularly clear in Spanish epigraphic studies, where Digital Image Modelling (hereafter DIM) is becoming a standard approach in epigraphic studies with the development of new data-share politics among research groups and museums. This is the case for example of the "Virtual Museum of Los Bañales" (Zaragoza, Spain) (Andreu Pintado 2018), where epigraphic and archaeological remains are being digitalised in order to make them available on the Internet, ${ }^{1}$ but also the case of the National Archaeological Museum in Madrid (Madrid, Spain) and the National Museum of Roman Art in Mérida (Badajoz, Spain), which offer an online selection of 3D models of Latin inscriptions in the "Epigraphia 3D" project (Ramírez Sánchez et al. 2015). ${ }^{2}$ Both cases are good examples of the expansion of 3D

\footnotetext{
${ }^{1} \mathrm{https}: / /$ sketchfab.com/banalesmuseovirtual

${ }^{2} \mathrm{http}: / /$ www.epigraphia3d.es/
} 
FINAL VERSION: Carrero-Pazos, M., Espinosa-Espinosa, D. 2018. Tailoring 3D modelling techniques for epigraphic texts restitution. Case studies in deteriorated roman inscriptions. Digital Applications in Archaeology and Cultural Heritage, vol 10. e00079 https://doi.org/10.1016/j.daach.2018.e00079

modelling through epigraphic studies, using WebGL platforms (e.g. "Sketchfab", "Verold Studio", "P3D") or electronic devices, such as tablets or smartphones (Ramírez Sánchez et al. 2014; Ramírez-Sánchez, Guerra Soto 2016; Barmpoutis, Bozia 2017).

These efforts have also been materialised in the creation of transnational digital repositories of inscriptions and public databases such as "EAGLE. Europeana network of Ancient Greek and Latin Epigraphy" (Orlandi et al. 2014; Orlandi 2015). ${ }^{3}$ All of them are benefit from the accuracy obtained by $3 \mathrm{D}$ modelling techniques, increasing the precision of results compared to regular bidimensional pictures or hand-made models (Guidi et al. 2014: 55). However, the possibilities of DIM by far surpasses the dissemination of archaeological artefacts, being the basis of new researches which aim to virtually enhance the grooves in order to better read the motifs (see e.g., Correia Santos et al. 2014; Frasson 2014; Pires et al. 2014a; 2015; Carrero-Pazos et al. 2018). This would be of great help in Galicia (NW of Iberian Peninsula), where the systematization works of the currentlyknown Roman inscriptions made by scholars such as G. Pereira Menaut or A. Rodríguez Colmenero during the nineties can be now complemented and precised. In this region, it is common that Latin inscriptions were carved in granite stones and the problems regarding their conservation are extremely usual. In fact, as a large number is in a poor state of preservation, their study is in many cases an important challenge. This fact has prompted the use of different recording methods, with works centred on the use of series of photographs with ranking light or others which make rubbings by frottage technique (see e.g., Pereira Menaut 1991). However, these techniques do not resolve reading problems, letters that can change the meaning of the whole inscription or allegedly illegible texts.

In this paper two case studies of Roman inscriptions from the ancient Gallaecia are presented. Starting from the 3D model creation by dense photogrammetry, we applied post-processing techniques to better read the eroded inscriptions. The application of these new techniques in future works on Galician inscriptions will allow us to complete and improve the existing corpora of Roman inscriptions from Galicia, as well as to achieve a deeper knowledge of the role that this region played under the Roman Empire. ${ }^{4}$ Finally, this paper aims to show the potential and usefulness of DIM techniques to study rock surfaces; methods that can be applied to other materials, such as bronze plaques and in other areas with similar conservation problems.

\section{Preservation problems}

Latin inscriptions in Galicia generally share three kinds of problems that can qualify the success of an epigraphic restitution work: the state of preservation, the level of expertise of the lapicidae that carved the tituli (i.e., epigraphic texts), and the peculiarities of the epigraphic habit in this historical region. Apart from this, in specific territories of the

\footnotetext{
${ }^{3}$ https://www.eagle-network.eu/

${ }^{4}$ This is the aim of the ongoing project "Epigraphica 3.0: Towards the Creation and Design of a Digital Corpus of Latin Inscriptions from the Province of Ourense", funded by the Regional Government of Galicia and leaded by D. Espinosa-Espinosa (2017-2019).
} 
FINAL VERSION: Carrero-Pazos, M., Espinosa-Espinosa, D. 2018. Tailoring 3D modelling techniques for epigraphic texts restitution. Case studies in deteriorated roman inscriptions. Digital Applications in Archaeology and Cultural Heritage, vol 10. e00079 https://doi.org/10.1016/j.daach.2018.e00079

Roman Empire such as Iberian Peninsula (particularly areas of Galicia, "Meseta", Extremadura and Portugal), the use of granite blocks to build this monuments helped the advancement of erosion processes, which often makes difficult to carry out a reliable epigraphic reading. These problems are well known as have already been pointed out by scholars such as Le Roux and Tranoy (1973: 221), indicating that "dans le Nord-Ouest de la Péninsule, les inscriptions d'époque romaine offrent au chercheur des problems de lecture et d'interprétation fréquents pour ne pas dire permanents. Il est de la sorte difficile de parvenir du premier coup à l'établissement correct du texte; il est nécessaire de revenir sans cesse à l'inscription, de l'interroger, en tous sens pour pouvoir proposer en toute honnêteté une solution satisfaisante. Le granit explique en partie ces écueils, mais il s'y ajoute l'état des monuments souvent réemployés et l'onomastique humaine et divine très particulière dans ces regions."

The granite is one of the most durable stones used in artistic and architectural applications since the most remote ancient times (Edmondson 2006: 19-20). It is a visibly granular igneous-rock which generally ranges in color from pink to light or dark grey, consisting mostly of quartz and feldspars and accompanied by one or more dark minerals. In addition to the quartz and feldspars, granite may also contain other minerals such as mica, hornblende and occasionally pyroxene (Pitcher 1997). Compared to calcareous sandstones, marble and limestone, granite is not an acid soluble stone and is much more resistant to the effects rainwater. However, despite its good physical qualities, the main problem of this stone is the gradual deterioration. This is due to natural processes, such as the mechanical and biological weathering. Regarding the former, granite blocks suffer the so-called "sandy disaggregation" or "granular disaggregation", which is the loss of cohesion among the mineral grains. This means an important loss of granite mass at the edges and carved surfaces. The second erosion process is caused by the biological colonization of lichens and mosses. These living organisms grow on the granite blocks surfaces due to favorable weather conditions, and create a more humid chemical microenvironment. The attachment of these organisms to the rock surface enhances physical and chemical breakdowns of the surface microlayer of the rocks (Silva 1992; Vicente et al. 1996; Rivas et al. 2002; Zambell et al. 2012).

These natural processes mean that the epigraphic field of granite inscriptions is frequently very pitted or eroded, which makes the original titulus difficult to read (Figure 1). Furthermore, in many cases natural fractures and marks are mixed with the grooves of the letters and the result is a wide range of possible readings. This is precisely the problem of the two case studies set out below, which were selected in order to show the possibilities of the application of 3D modelling techniques on hard-to-read inscriptions, aiming a new and more accurate reading.

Figure 1. Granite inscriptions in poor state of preservation. A: Santa María do Viso, Redondela (CIRG II, 145). B: Funerary plaque of Ponte de Brandomil, Zas (CIRG I, 43).

\section{Case studies}


FINAL VERSION: Carrero-Pazos, M., Espinosa-Espinosa, D. 2018. Tailoring 3D modelling techniques for epigraphic texts restitution. Case studies in deteriorated roman inscriptions. Digital Applications in Archaeology and Cultural Heritage, vol 10. e00079 https://doi.org/10.1016/j.daach.2018.e00079

\subsection{CIRG I, 35: Funerary plaque from A Cidadela (Sobrado dos Monxes, A Coruña) ${ }^{5}$}

The first case study is an epitaph from the surrounding area of the Roman camp of A Cidadela, where the cohors I Celtiberorum equitata civium Romanorum was established in the early second century A.D. (Costa García 2013; Caamaño Gesto, Carlsson-Brandt Fontán 2015). It is a granite plaque found at the beginning of the last century (Balsa de la Vega 1909: 28-30; Fita Colomé 1910: 359), later transferred to Santiago de Compostela (García Romero 1909: 147; 1913: 101) (Figure 2).

Figure 2. The funerary plaque from A Cidadela, currently located at the Cathedral Museum in Santiago de Compostela.

The length, height and width measurements are $67 \times 72 \times 12 \mathrm{~cm}$ respectively, remaining incomplete at the bottom. The plaque, currently located at the Cathedral Museum in Santiago de Compostela, was dated by G. Pereira Menaut (1991: 91 and 225) in the second or third century A.D. due to the presence of the formula Dis Manibus sacrum (López-Barja 1993: 37; Andreu Pintado 2009: 345; González García 2010: 403; Cooley 2012: 421) and the proximity to the Roman camp of A Cidadela, dated in the early second century A.D. ${ }^{6}$

Concerning the epigraphic text restitution, the following table records the main readings managed by scholars at the beginning of the last century (Table 1):

Table 1. Main readings of the funerary plaque of A Cidadela.

Despite the efforts made by these scholars to achieve a reliable reading of this titulus, the discussion remained open with several versions suggested on this previous basis (Table 2):

Table 2. Minor changes on the different reading versions of the funerary plaque of $A$ Cidadela.

\subsection{CIRG II, 37: Stele from Santa María de Cela (Bueu, Pontevedra)}

The second case study is also a funerary titulus, from Sabarigo in Santa María de Cela. This inscription was studied for the first time in 1976 by Fariña Busto and García Alén (1979), and is a medium-grain granite elongated block that is well preserved. Nevertheless, the monument shows a small breaking at the top of the epigraphic field which slightly affects the beginning of the text and the moulding (Figure 3).

\footnotetext{
5 Although the official name is A Ciadella, in this work we opted for A Cidadela, widely used in archaeological and epigraphic works.

${ }^{6}$ This date seems to fit well also with the fact that the deceased person's name does not provide praenomen, a rare situation in the inscriptions from the end of the second century A.D., as well as with the tendency to abridge the nomina through his first three or four letters (López-Barja 1993: 37).
} 
FINAL VERSION: Carrero-Pazos, M., Espinosa-Espinosa, D. 2018. Tailoring 3D modelling techniques for epigraphic texts restitution. Case studies in deteriorated roman inscriptions. Digital Applications in Archaeology and Cultural Heritage, vol 10. e00079 https://doi.org/10.1016/j.daach.2018.e00079

Figure 3. The funerary stele from Santa María de Cela, currently stored at the Museum of Pontevedra.

With regard to the stele's dimensions, the length, height and width measurements are 47 x 180 x $23 \mathrm{~cm}$ respectively, including an epigraphic field of $36 \mathrm{~cm}$ length and $47 \mathrm{~cm}$ height. The characters are capital letters of different size -ranging between 4 and $7 \mathrm{~cm}-$ sloppily carved.

This stele has been dated by Fariña Busto and García Alén (1979: 322) in the second half of the third century A.D., although afterwards Baños Rodríguez (1994: 25) proposed an undefined moment from the second century A.D. using parallel cases (see for further Fariña Busto, García-Alén 1979: 319-320; Baños Rodríguez 1994: 103; González García 2010: 406). ${ }^{7}$ The main readings of the inscription are shown in Table 3.

Table 3. Main readings of the funerary stele from Santa María de Cela.

As can be concluded from Table 3, despite the well-preserved state of this stele, the epigraphic text has not been certainty established, basically for three main reasons: the erosion of the epigraphic field; the shallow depth of the groove of the letters, and the apparent lack of expertise of the lapicida. This has resulted in serious problems to know exactly the deceased person's name, as well as if the name of the dedicator was carved on the monumentum.

\section{Methodology: Photogrammetry SfM}

This work is focused on the creation of scaled 3D models to better document and read two selected inscriptions. The methodological process was done using Dense Photogrammetry, via the commercial computer vision-based software Agisoft Photoscan.

The photogrammetry Structure from Motion (SfM) is a passive-sensor technique which mainly allows the derivation of metric information from a series of photographs, taking into account camera calibration and image orientation. It produces a three dimensional model from a mathematical processing of the image data, creating a sparse or dense cloud (Remondino 2014). As all the information is extracted from the photographs, the image acquisition is the most important part of the methodology, and was carried out here following the standard principles of overlapping (Agisoft LLC 2016; Verhoeven 2011: 71). For the recording process, a 18 megapixel Cannon EOS 1200D commercial reflex camera was used. For the computational process, a MSi Intel Core (TM) i7-4712 MQ CPU $2.30 \mathrm{GHz}$ with $16 \mathrm{~GB}$ ram and a Nvidia GeForce $820 \mathrm{M}$ was used, working on Windows 10 operating system (Figure 4).

\footnotetext{
${ }^{7}$ It is noteworthy that this timeframe fits well with the fact that the formula Dis Manibus goes together with the expression in memoriam or memoriam posuit, a situation that is more common since the end of the second century A.D. (López-Barja 1993: 37; Ciprés 2006: 93, 102, 127; Andreu Pintado 2009: 345; Bruun, Edmondson 2015: 642-643), although in other regions of Hispania it seems to be earlier (González Román 1996: 370-372).
} 
FINAL VERSION: Carrero-Pazos, M., Espinosa-Espinosa, D. 2018. Tailoring 3D modelling techniques for epigraphic texts restitution. Case studies in deteriorated roman inscriptions. Digital Applications in Archaeology and Cultural Heritage, vol 10. e00079 https://doi.org/10.1016/j.daach.2018.e00079

Figure 4. Survey data: camera locations (Agisoft Photoscan Software).

In order to obtain accurate metric information from the 3D model, a small scale of $40 \mathrm{~cm}$ was placed over the panels, later removed from the 3D model. Once the set of images were taken, the image processing steps started. For this purpose, Agisoft Photoscan worked automatically taking the matches in the 2D images from different perspectives, based on a combination of SfM and a variety of dense multi-view stereo (MVS) algorithms (Ullman 1979; Seitz et al. 2006; Doneus et al. 2011; Verhoeven 2011; Verhoeven et al. 2012; Plets et al. 2012).

The first part of the workflow was the image alignment. The process was done by Photoscan using the correlated points among overlapped 2D images, calculating the position and orientation of the cameras. With this information, a 3D spare point cloud was generated, which was manually cleaned up to eliminate the residual points (Figure 5: A). In a second step, an MVS approach calculated a meshed 3D model (Figure 5: B), and next the 3D model was texturised basing on photographs (Plets et al. 2012: 147) (Figure 5: C).

Figure 5. Steps of 3D modelling. A: 3D spare point cloud. B: Meshed 3D model. C: Texturised 3D model.

Later, we used the small scale to set two reference points, defining the distance between them to get the 3D model rescaled and once this was done, the scale was removed from the model. From here, the 3D model was exported to a Standard PLY file to be treated with digital enhancement techniques (Figure 6).

Figure 6. Camera Information and data characteristics of the photogrammetric study.

\section{Application of Digital Imaging Techniques}

The study of both ortho-images extracted from the 3D model gives a first view of the state of preservation of both inscriptions (Figure 7).

Figure 7. Ortho-images extracted from 3D model. A: Funerary plaque from A Cidadela. B: Funerary stele from Santa María de Cela.

The funerary plaque of A Cidadela shows important preservation problems due to erosion and breakings, but the case of Santa María de Cela is much better preserved. A preliminary analysis of the untexturised 3D model with artificial lights is commonly used to check the different parts of the inscriptions (Fernández Díaz et al. 2016), which shows some interesting results at first glance (Figure 8).

Figure 8. Artificial light analysis of both inscriptions with different light angles. A: Funerary plaque of A Cidadela. B: Funerary stele from Santa María de Cela.

From Figure 8 we can retain that the inscription of A Cidadela consists of a wide mold which increases its size at the top as semicircular crown. This mold delimits a broad epigraphic field with seven preserved lines that seems to have received a suitable and 
FINAL VERSION: Carrero-Pazos, M., Espinosa-Espinosa, D. 2018. Tailoring 3D modelling techniques for epigraphic texts restitution. Case studies in deteriorated roman inscriptions. Digital Applications in Archaeology and Cultural Heritage, vol 10. e00079 https://doi.org/10.1016/j.daach.2018.e00079

careful ordinatio. Despite this, the text displayed in the first line of the titulus appears moved to the left, and the ductus of the letters is irregular and careless. The characters, with an overall height of $4-5 \mathrm{~cm}$, are capital letters with a clear tendency towards the cursive writing. The lack of expertise of the lapicida as well as the erosion and blows which have affected certain parts of the monumentum makes the epigraphic text restitution uncertain, resulting in different possible readings. ${ }^{8}$

The case of Santa María de Cela is very much promising. The inscription is divided into four parts, being the upper one a smooth surface with a rounded top as a semicircular crown, in which a deep semicircular groove and a negative lunar crescent pointing upwards were carved. ${ }^{9}$ The middle part is also further divided into two parts. The first one is a depressed surface acting as a niche, with a positive nude human figure standing and facing forward. Such figure has been awkwardly made, and it shows a big head with ears that protrude too far from the head, open hands on the hip and feet depicted facing right. The second part is also a depressed surface delimited by a smooth moulding on the whole sides. That is the six-line epigraphic field in which the inscription was carved. The ordinatio was not carefully executed and the ductus of the letters is irregular and careless.

From the artificial lights analysis, two different types of carving styles can also be distinguished, being in the case of Sobrado dos Monxes a more robust way of inscribe than in Santa María de Cela, which shows a stylistic stroke (Figure 9).

Figure 9. Stylistic stroke differences between both inscriptions.

\subsection{Radiance Scaling and mesh comparison}

Starting from the virtual lights approach, further methods can be applied, such as the use of Radiance Scaling MeshLab shader, a technique which dependently modifies the reflected light intensities on surface curvature and material characteristics. The results enhance the concavities and convexities of the 3D model's surface (Vergne et al. 2010: 1). This technique was used for the first time over inscriptions to facilitate the reading of the motifs (Granier et al. 2012), but nowadays its use is widespread in rock art studies (see i.e. Medici, Rossi 2015; Vilas-Estévez et al. 2015; Carrero-Pazos et al. 2017; LópezMenchero Bendito et al. 2017).

Among the different options that can be implemented on MeshLab, we can use the Lambertian Radiance Scaling which highlights the cavities of the 3D model in grey tones (Figure 10: A), although further options such as the Lit Sphere Radiance Scaling usually give better results. In that case, a lit sphere encodes the lighting environment and its reflective properties into an image of a sphere, and a different sphere can be used for convex and concave regions (Granier et al. 2012). Following the work of Vilas-Estévez

\footnotetext{
${ }^{8}$ In this respect, García Romero (1913: 102) pointed out four factors that complicate the reading of this inscription: a granite stone of coarse grit, the absence of interpunctions, the shallow and irregular letters, and (as already mentioned) the inexperience of the scriptor titulorum.

${ }^{9}$ It was designed as a semicircular crown with a curved projection on each side, which seemed to be a schematization of two acroterions if we consider similar cases (see for further Fariña Busto, García-Alén 1979: 318 and 321; González García 2010: 407-408).
} 
FINAL VERSION: Carrero-Pazos, M., Espinosa-Espinosa, D. 2018. Tailoring 3D modelling techniques for epigraphic texts restitution. Case studies in deteriorated roman inscriptions. Digital Applications in Archaeology and Cultural Heritage, vol 10. e00079 https://doi.org/10.1016/j.daach.2018.e00079

(et al. 2017), instead of using the pre-set spheres accessible in MeshLab, we used a red and yellow ones which allows a better visualisation of the inscriptions (Figure 10: B).

One interesting alternative to common radiance scaling shader is the use of a comparative approach between two meshes, approach that can also be achieved in MeshLab. The methodological approximation of this method (Cassen et al. 2014; Pires et al. 2014a,b; Grimaud 2015) is centred on the comparison between the original mesh and a decimated pre-smoothed one, which avoid small details of the 3D model allowing a better enhancement of the carvings. Following the work of Pires (et al. 2014b), we used the edge collapse decimation filter with a $90 \%$ of reduction factor to produce a coarse decimation model similar to the original one, applying in a second step the Laplacian smoothing filter to get a smoothed surface of the inscriptions which substantially reduced the noise. This resulting trend mesh was then subtracted from the original one, getting the carvings enhanced. This approximation usually allows an interesting highlight of the details of the 3D model (Figure 10: C).

Figure 10. Application of Radiance Scaling to both inscriptions. A: Lambertian Radiance Scaling. B: Radiance Scaling with red and yellow spheres. C: Comparison of meshes.

\subsection{Ambient occlusion and colour mapping derivatives}

Although Radiance Scaling is a highly recommendable first analysis to study the features of a 3D model for its faster application, sometimes the surface is diffuse and it does not properly depict the details. For that, the application of the ambient occlusion technique is other complement, which helps the visualisation of the geometric features of the inscriptions giving a measure of the occlusion of the different parts of the 3D model, showing in darker tones the most self-occluded parts and in lighter ones those more exposed to light (Figure 11: A). As the ambient occlusion is calculated as colour information, these values can be stored and preserved on the 3D model, going further the limitations of a shader (Carrero-Pazos et al. 2017). Ambient occlusion technique can also be improved to re-enhance the carvings using Radiance Scaling Lambertian option, as shown in Figure 11: B.

Furthermore, colour mapping techniques can also be used, such as computing the curvature principal directions of the $3 \mathrm{D}$ model and colouring their mean curvature (Figure 11: C). In this case, the pseudoinverse quadric fitting colour mapping available in MeshLab was the analysis used. As it is a colour mapping approach, we can use different colour palettes, as shown in part $\mathrm{C}$.

Figure 11. Ambient occlusion and colour mapping derivatives applied to both inscriptions. A: Ambient occlusion. B: Ambient occlusion plus Radiance Scaling Lambertian. C: Colour mapping through the mean curvature of the 3D model.

\section{Discussion. Towards a more accurate reading of the case studies}

a) Funerary plaque from A Cidadela (CIRG I, 35) 
FINAL VERSION: Carrero-Pazos, M., Espinosa-Espinosa, D. 2018. Tailoring 3D modelling techniques for epigraphic texts restitution. Case studies in deteriorated roman inscriptions. Digital Applications in Archaeology and Cultural Heritage, vol 10. e00079 https://doi.org/10.1016/j.daach.2018.e00079

Based on the analytical processes carried out and accordingly the achieved results, we can now provide a more accurate reading for the selected case studies. In relation to the funerary plaque from A Cidadela, the epigraphic text restitution presents some challenges in specific parts as the epigraphic field has important weathering, particularly at the bottom part. We suggest the following reading:

$\mathrm{D}$ (is) M(anibus) s(acrum) / Val(erio) Antẹ / ro Tiami / XXXV Fron / ia Fronia $\square<\mathrm{a}>$ / coniuĝ̀i / çaris $\square \mathbf{i} \square \mathbf{o} /$ [------] ?

The reading of this inscription does not offer important problems until the fifth line. In the first line, as it is known since the first proposals made by García Romero and Fita Colomé in 1910, the formula Dis Manibus sacrum with abbreviation is moved to the left. In the second and third lines, the deceased person's name in dative case is recognised. It consists of duo nomina plus filiation with no filiation marker: Valerius Anterus Tiami. The only potential difficulty is the letter E belonging to Anterus, which is partially damaged for a probable blow. In contrast to the wide dissemination of the nomen Valerius (which appears here with abbreviation), the cognomen Anterus is not very well known. As Le Roux and Tranoy (1973: 224) had pointed out, this cognomen is documented only in Abertura in Cáceres, ${ }^{10}$ whereas the form Antelus is more common. ${ }^{11}$ According to Albertos Firmat (1966: 293), the alternation of the suffix "-l" with the suffix "-r" in the same radical element seems to be usual in the Celtic languages, so both forms could be connected. Regarding the name Tiamus, García Romero (1910: 263) links it to the form Thiamus documented in Oliva de Plasencia in Cáceres, ${ }^{12}$ while for Le Roux and Tranoy (1973: 224) is a hapax. However, there is an altar from Valdeolea in Cantabria, ${ }^{13}$ in which González Echegaray and Casado Soto (1979-1980: 241) proposed Tiamus as the dedicator's name. This onomastic structure is incorrect from a strictly Roman point of view, since the correct order would have been nomen, filiation and cognomen (i.e., Valerius Tiami Anterus). Nevertheless, scholars such as Dondin Payre (2001, 2004), Ciprés Torres (2006) and González Rodríguez (2011) have provided numerous examples of this structure in Hispania, Gallia and Africa Proconsularis.

The fourth and fifth lines are the place where the lapicida carved the deceased's age and dedicator's name. Concerning the first, Valerius Anterus died at the age of 35. In his memory and honour, Fronia Froniana set this monument up. The name of the dedicator consists of two ones, with a unique reliable parallel case for Fronia in Palestrina, Italy. ${ }^{14}$ However, the name Fronius is well documented in inscriptions from Carthage and Lamta in Africa Proconsularis, Cagliari in Sardinia, Saluzzo, Chiusi and Velletri in Italy, and Friedberg in Germany. ${ }^{15}$ Therefore, it seems possible to discard the readings Fronia

\footnotetext{
${ }^{10}$ ILER 348.

${ }^{11}$ See the cases of Vilches (Jaén) (EE IX, 327), Santa Marinha (Ribeira de Pena, Vila Real) (CIL II, 2387), Worms (Germany) (CIL XIII, 6216) and Bruckneudorf (Austria) (AE 2002, 1137).

${ }^{12}$ CIL II, 823.

${ }^{13} A E$ 1994, $1024=H E p ~ 5,1995,291$.

${ }^{14}$ EE IX, 881.

15 See CIL VIII, 22644, 259a; CIL VIII, 22644, 259b; BCTH 1897, 311; CIL X, 8053,084c; CIL V, 8114, 055e; CIL XI, 2506; CIL XV, 6453; CIL XIII, 10001, 382.
} 
FINAL VERSION: Carrero-Pazos, M., Espinosa-Espinosa, D. 2018. Tailoring 3D modelling techniques for epigraphic texts restitution. Case studies in deteriorated roman inscriptions. Digital Applications in Archaeology and Cultural Heritage, vol 10. e00079 https://doi.org/10.1016/j.daach.2018.e00079

Irenia (García Romero 1910; 1913), Iulia Aproniana (Fita Colomé 1910; 1911; Pereira Menaut 1991) and Fronia Fronta (Le Roux, Tranoy 1973).

Finally, in relation to the two last lines, we find the kind of link that brings Valerius Anterus and Fronia Froniana together: the marriage. In accordance with the titulum, the dedicator set up the plaque to her very beloved husband (coniugi carissimo). This dativecase expression is poorly seen due to the state of preservation, with probable evidence of ligatures of G-I, and C-A respectively. For that, as Le Roux and Tranoy (1973) had already suggested, the presence of more lines cannot be excluded.

\section{b) Stele from Santa María de Cela (CIRG II, 37)}

The good state of preservation of this monument has allowed us to propose a more confident reading, which confirms the variant published by Baños Rodríguez in 1994, ${ }^{16}$ with the interpunction suggested in the journal Hispania Epigraphica (HEp 6, 2000, 709):

Dibus M / anibu / s mem / ori $<\mathrm{a}>\mathrm{m} /$ Pusinc(ae) $\cdot /$ an(n)o(rum) L

The first most striking aspect is regarding the adprecatio Manibus, because apart from being carved with no abbreviation, the lapicida misspelled the dative case (for masculine and plural) of deus. As it is well known, the right way would be dis or diis. Concerning the expression in memoriam or memoriam posuit, neither do we see evidence of a possible ligature of A and M (such as Fariña Busto and García Alén 1979 proposed), so the scriptor titulorum seems to have forgotten the letter A. Finally, in the fifth line, we can clearly read Pusinca, as Baños Rodríguez (1994) had suggested. This name in genitive case is known in Italia, Mauretania Tingitana and particularly in Hispania (Albertos Firmat 1966; Abascal Palazón 1994; Vallejo Ruiz 2016). ${ }^{17}$ Thus, the first reading of Fariña Busto and García Alén (1979), who proposed Pusinna, seems to be now discarded. The titulum ends with the abbreviated expression annorum, and the deceased's age is 50 years in this case.

\section{Conclusions}

The application of 3D modelling techniques has allowed us to obtain more sound readings of both inscriptions. In the case of A Cidadela's stele, we have concluded the discussion of the deceased's name (Valerius Anterus Tiami) and his wife (Fronia Froniana). With regard to the stele from Santa María de Cela, the results suggest that Pusinna is not the name of the deceased and, therefore, we should read Pusinca.

\footnotetext{
${ }^{16}$ CIRG II, 37.

17 See $A E$ 1978, 342 (Bondeno/Ferrara); AE 1942-1943, 24 (Volubilis); CIRG I, 43 (Brandomil, Zas, A Coruña), EE IX, 312 = ILER 4005 (Alcalá de Henares, Madrid); HEp 15, 2006, 258 (Torrejón de Ardoz, Madrid); HEp 2, 1990, 423 (Torrejón del Rey/Galápagos, Guadalajara); $A E$ 1968, 210 (Esparragalejo, Badajoz).
} 
FINAL VERSION: Carrero-Pazos, M., Espinosa-Espinosa, D. 2018. Tailoring 3D modelling techniques for epigraphic texts restitution. Case studies in deteriorated roman inscriptions. Digital Applications in Archaeology and Cultural Heritage, vol 10. e00079 https://doi.org/10.1016/j.daach.2018.e00079

To sum up, this paper has shown the possibilities of Digital Image Modelling for the study of Roman inscriptions in poor state of preservation. We intended to demonstrate how the use of Photogrammetry SfM alongside digital imaging techniques such as Radiance Scaling, Ambient occlusion or mesh comparison have great potential for 3D recording and documenting stone inscriptions, mostly in the epigraphic restitution of ancient texts, providing more accurate and reliable readings in cases of poor state of preservation. In addition, the analytical approaches described here can be applied to other materials, such as bronze or wood carved inscriptions, with highly probable interesting results.

Despite the wide range of possibilities they offer, the use of DIM techniques does not discard the application of traditional methods such as ranking light or rubbings done by frottage technique. The analyses carried out in this paper clearly assisted in providing more precise readings, but it was the comparison with other methods -such as artificial lighting and the expertise of the epigrapher- which allowed a final reading proposal.

From a more technically point of view, DIM techniques allow a faster and accurate record of the inscriptions than traditional manually methods, an interesting point in case of limited time or bad weather conditions during fieldwork. On the other hand, the use of $3 \mathrm{D}$ models in epigraphic research is opening new faces towards data sharing, as 3D files can easily be uploaded at online platforms or shared by private systems. This is certainly changing the concept of research in Archaeology, specifically in epigraphic studies, with more precise and trustworthy information publicly accessible through projects like EAGLE, or the ongoing one in Galicia "Epigraphica 3.0: Towards the Creation and Design of a Digital Corpus of Latin Inscriptions from the Province of Ourense (Galicia, NW of Iberian Peninsula)" carried out by the authors, which will contribute to build new perspectives for epigraphic research in this region.

\section{Acknowledgements}

Authors are grateful to the Cathedral Museum of Santiago de Compostela, the Museum of Pontevedra and the Epigraphic Archive of Hispania in Madrid for the access to the inscriptions and their related information, especially to Ramón Yzquierdo Peiró, Antonio de la Peña Santos, M. ${ }^{\mathrm{a}}$ Rosario Hernando Sobrino and Paloma Balbín Chamorro.

David Espinosa-Espinosa is funded by the Regional Government of Galicia through a Postdoctoral Fellowship (I2C Plan 2014-2019).

Some of the analytical improvements of this paper were developed thanks to the participation of Miguel Carrero-Pazos in the TNA Summer School "2D/3D Documentation for Archaeology" (ISTI-CNR, Visual Computing Lab, Pisa, 2016), with funding from the European Commission Seventh Framework Programme (under grant agreement P7-INFRASTRUCTURES-2012-1-313193 [ARIADNE]). Mateo Dellepiane, Marco Callieri and Roberto Scopigno provided appreciated advises concerning MeshLab processing stages. 
FINAL VERSION: Carrero-Pazos, M., Espinosa-Espinosa, D. 2018. Tailoring 3D modelling techniques for epigraphic texts restitution. Case studies in deteriorated roman inscriptions. Digital Applications in Archaeology and Cultural Heritage, vol 10. e00079 https://doi.org/10.1016/j.daach.2018.e00079

The final version of the paper has undoubtedly benefitted from the contribution of anonymous reviewers.

\section{References}

Abascal Palazón, J. M., 1994. Los nombres personales en las inscripciones latinas de Hispania. Universidad de Murcia, Murcia.

$A E=$ L'Année épigraphique. Revue des publications épigraphiques relatives à l'Antiquité romaine. Paris.

Agisoft LLC. 2016., Agisoft PhotoScan User Manual: Professional Edition, Version 1.2. Moscow.

Albertos Firmat, M. ${ }^{\mathrm{a}}$ L., 1966. La onomástica personal primitiva de Hispania Tarraconense y Bética. Instituto Antonio de Nebrija (CSIC), Salamanca.

Andreu Pintado, F. J. (ed.), 2009. Fundamentos de Epigrafía latina. Liceus, Madrid.

Andreu Pintado, F. J. 2018. Museo histórico y arqueológico virtual "Los Bañales": fotogrametría 3D al servicio de la puesta en valor del patrimonio arqueológico y de la formación universitaria. Cuadernos del Marqués de San Adrián, Número Extraordinario 2018, 25-32.

Babeu, A. 2011. "Rome Wasn't Digitized in a Day": Building a Cyberinfrastructure for Digital Classicists. Council on Library and Information Resources, Washington.

Balsa de la Vega, R., 1909. Enigma arqueológico. Boletín de la Real Academia Gallega 26, 27-31.

Barmpoutis, A., Bozia, E. 2017. Augmenting the workspace of epigraphists. An interaction design study, in: Orlandi, S., Santucci, R., Mabrini, F., Liuzzo, P. (eds.), Digital and Traditional Epigraphy in Context. Proceedings of the EAGLE 2016 International Conference (Rome, 2016). Sapienza Università Editrice, Roma, 2017, 209220.

Baños Rodríguez, G., 1994. Corpus de inscripcións romanas de Galicia. Vol. II: Provincia de Pontevedra (CIRG II). Consello da Cultura Galega, Santiago de Compostela.

Bouza Brey, F., d'Ors, Á., 1949. Inscripciones Romanas de Galicia. I: Santiago de Compostela (IRG I). Instituto Padre Sarmiento de Estudios Gallegos (CSIC), Santiago de Compostela.

Bruun, C., Edmondson, J., 2015. The Oxford Handbook of Roman Epigraphy. Oxford University Press, Oxford.

$B C T H=$ Bulletin archéologique du comité des travaux historiques et scientifiques, Paris. 
FINAL VERSION: Carrero-Pazos, M., Espinosa-Espinosa, D. 2018. Tailoring 3D modelling techniques for epigraphic texts restitution. Case studies in deteriorated roman inscriptions. Digital Applications in Archaeology and Cultural Heritage, vol 10. e00079 https://doi.org/10.1016/j.daach.2018.e00079

Caamaño Gesto, J.M., Carlsson-Brandt, E., 2015. Marcas de la cohors I Celtiberorum halladas en el campamento romano de Cidadela (Sobrado dos Monxes, A Coruña). Portugalia 36, 107-120.

Carrero-Pazos, M., Vilas-Estévez, B., Vázquez-Martínez, A., 2017. Making Visible the Invisible: Low Cost Methodologies for the Study of Ancient Carvings, in: MayoralHerrera, V., Parcero-Oubiña, C., Fábrega-Álvarez, P. (Eds.), Archaeology and Geomatics. Harvesting the benefits of 10 years of training in the Iberian Peninsula (20062015). Sidestone Press, Leiden, pp. 73-89.

Carrero-Pazos, M., Vilas-Estévez, B., Vázquez-Martínez, A., 2018. Digital Imaging Techniques for Recording and Analysing Prehistoric Rock Art Panels in Galicia (NW Iberia). Digital Applications in Archaeology and Cultural Heritage 8, 35-45.

Cassen, S., Lescop, L., Grimaud, V., Robin, G., 2014. Complementarity of acquisition techniques for the documentation of Neolithic engravings: lasergrammetric and photographic recording in Gavrinis passage tomb (Brittany, France). Journal of Archaeological Science 45, 126-140.

CIL II = Hübner, E. (Ed.), 1869. Corpus Inscriptionum Latinarum II. Inscriptiones Hispaniae Latinae, Berlin.

CIL V = Mommsen, Th. (Ed.), 1872, 1877. Corpus Inscriptionum Latinarum V. Inscriptiones Galliae Cisalpinae Latinae, Berlin.

CIL X = Mommsen, Th. (Ed.), 1883. Corpus Inscriptionum Latinarum X. Inscriptiones Bruttiorum, Lucaniae, Campaniae, Siciliae, Sardiniae Latinae, Berlin.

$C I L$ VIII = Mommsen, Th., Wilmanns, G. (Eds.), 1881. Corpus Inscriptionum Latinarum VIII. Inscriptiones Africae Latinae, Berlin.

CIL XI = Bormann, E. (Ed.), 1888-1926. Corpus Inscriptionum Latinarum XI. Inscriptiones Aemiliae, Etruriae, Umbriae Latinae, Berlin.

CIL XIII = Hirschfeld, O., Zangemeister, C. (Eds.), 1899. Corpus Inscriptionum Latinarum XIII. Inscriptiones trium Galliarum et Germaniarum Latinae, Berlin.

CIL XV = Dressel, H. (Ed.), 1891-1899. Corpus Inscriptionum Latinarum XV. Inscriptiones urbis Romae Latinae. Instrumentum domesticum, Berlin.

Ciprés, P., 2006. La onomástica de las inscripciones romanas del País Vasco. Estructura personal y estatuto jurídico. Veleia 23, 85-128.

Cooley, A. E., 2012. The Cambridge Manual of Latin Epigraphy. Cambridge University Press, Cambridge.

Correia Santos, M. J., Sousa, O., Pires, H., Fonte, J., Gonçalves Seco, L., 2014. Travelling back in Time to Recapture Old Texts: The use of Morphological Residual Model (MRM) 
FINAL VERSION: Carrero-Pazos, M., Espinosa-Espinosa, D. 2018. Tailoring 3D modelling techniques for epigraphic texts restitution. Case studies in deteriorated roman inscriptions. Digital Applications in Archaeology and Cultural Heritage, vol 10. e00079 https://doi.org/10.1016/j.daach.2018.e00079

for epigraphical reading. Information Technologies for Epigraphy and Cultural Heritage. Sapienza Universitá Editricie, Roma, 437-454.

Costa García, J. M., 2013. Arqueología de los asentamientos militares romanos en la Hispania Altoimperial (27 a.C. - ca. 280 d.C.). Universidade de Santiago de Compostela (Unpublished PhD Dissertation), Santiago de Compostela.

Edmondson, J., 2006. Granite funerary stelae from Augusta Emerita, Monografías Emeritenses 9. Ministerio de Cultura, Mérida.

$E E=$ Ephemeris Epigraphica Corporis Inscriptionum Latinarum supplementum, Berlin.

Fariña Busto, F., García Alén, A., 1979. La estela funeraria romana de Sabarigo (Sta. María de Cela, Pontevedra). Gallaecia 3-4, 317-326.

Fernández Díaz, M., Major González, M., Penedo Cobo, E., 2016. Proceso de digitalización y análisis de una inscripción romana: el caso del contrapeso del torcularium de los Palacios (Villanueva del Pardillo, Madrid). Revista Otarq 1, 285-299.

Fita Colomé, F., 1910. Nuevas lápidas romanas del norte de Galicia. Boletín de la Real Academia de la Historia 56, 351-363.

Fita Colomé, F., 1911. Nuevas lápidas romanas de Noya, Cando, Cerezo y Jumilla, Boletín de la Real Academia de la Historia 59, 398-417.

Frasson, F. 2014. Image editing programs as tools for the study of ancient inscriptions, in: Orlandi, S., Santucci, R., Casarosa, V., Liuzzo, P. (eds.), Information technologies for epigraphy and cultural Heritage. Proceedings of the first EAGLE International Conference (París, 2014), Sapienza Università Editrice, Roma, 145-152.

García Romero, C., 1909. Las lápidas romanas de Ciudadela. Boletín de la Real Academia Gallega 31, 147-149.

García Romero, C., 1910. Las lápidas romanas de Ciudadela II. Boletín de la Real Academia Gallega 35, 262-263.

García Romero, C., 1913. Las lápidas romanas de Ciudadela III. Boletín de la Real Academia Gallega 76, 101-105.

González García, F. J., 2010. Hábito epigráfico, decoración plástica e interacción cultural en el Noroeste hispano en época romana. Análisis de las estelas funerarias de Vigo (Pontevedra). Madrider Mitteilungen 51, 397-418.

González Echegaray, J., Casado Soto, J. L., 1979-1980. Dos nuevas inscripciones romanas en Cantabria. Altamira. Revista del Centro de Estudios Montañeses 42, 235-241.

González Rodríguez, M. ${ }^{\mathrm{a}}$ C., 2011. En torno a la expresión de la origo en el Noroeste hispano: el caso de los cántabros vadinienses como ejemplo de integración cívica, in: 
FINAL VERSION: Carrero-Pazos, M., Espinosa-Espinosa, D. 2018. Tailoring 3D modelling techniques for epigraphic texts restitution. Case studies in deteriorated roman inscriptions. Digital Applications in Archaeology and Cultural Heritage, vol 10. e00079 https://doi.org/10.1016/j.daach.2018.e00079

Iglesias Gil, J. M., Ruiz Gutiérrez, A. (Eds.), Viajes y cambios de residencia en el mundo romano. Ediciones de la Universidad de Cantabria, Santander, pp. 93-117.

González Román, C., 1996. Inscripciones romanas de la provincia de Jaén: Supplementum (II). Florentia Iliberritana 7, 369-379.

Granier, X., Vergne, R., Pacanowsky, R., Barla, P., Reuter, P., 2012. Enhancing Surface features with the radiance scaling MeshLab plugin, in: Graeme, E., Sly, T., Chrysanthi, A., Murrieta-Flores, P., Papadopoulos, C., Romanowska, I., Wheatley, D. (Eds.), Archaeology in the Digital Era, Volume II. Amsterdam University Press, Amsterdam, pp. 417-422.

Grimaud, V., 2015. Réexplorer et valoriser les architectures funéraires monumentales du Néolithique de l'Ouest de la France. Etude du cairn de Gavrinis. Unpublished PhD Dissertation, Université de Nantes Angers le Mans, Nantes.

Guidi, G., Ruso, M., Angheleddu, D., 2014. 3D survey and virtual reconstruction of archaeological sites. Digital Applications in Archaeology and Cultural Heritage 1 (2), 5569.

$H E p=$ Hispania Epigraphica (Archivo Epigráfico de Hispania). Universidad Complutense de Madrid, Madrid.

Le Roux, P., Tranoy, A., 1973. Notes d'épigraphie romaine de Galice. Cuadernos de Estudios Gallegos 28 (85), 221-234.

López-Barja de Quiroga, P., 1993. Epigrafía latina. Las inscripciones romanas desde los orígenes al siglo III d.C. Tórculo, Santiago de Compostela.

López-Menchero Bendito, V. M., Marchante Ortega, Á., Vincent, M. L., Cárdenas Martín-Buitrago, Á. J., Onrubia Pintado, J., 2017. Uso combinado de la fotografía digital nocturna y de la fotogrametría en los procesos de documentación de petroglifos: el caso de Alcázar de San Juan (Ciudad Real, España).Virtual Archaeology Review 8 (17), 6474.

Medici, P., Rossi, G., 2015. Valcamonica 3.0: a new dimension in rock art recording. From tracing to structure from motion and postprocessing, in Troletti, F. (Ed.), Research Perspectives on Prehistoric Art, Proceedings of the XXVI Valcamonica Symposium, Capo di Ponte (9th -12th September 2015). Ediciones del Centro, Capo di Ponte, pp.163168.

Orlandi S., Giberti L., Santucci R., 2014. EAGLE - Europeana network of Ancient Greek and Latin Epigraphy: Making the ancient inscriptions accessible, Lexicon Philosophicum 2, 315-326.

Orlandi, S., 2015. The EAGLE network. Archeologia e Calcolatori 26, 21-22. 
FINAL VERSION: Carrero-Pazos, M., Espinosa-Espinosa, D. 2018. Tailoring 3D modelling techniques for epigraphic texts restitution. Case studies in deteriorated roman inscriptions. Digital Applications in Archaeology and Cultural Heritage, vol 10. e00079 https://doi.org/10.1016/j.daach.2018.e00079

Pereira-Menaut, G., 1991. Corpus de inscripcións romanas de Galicia. Vol. I: Provincia de A Coruña (CIRG I). Consello da Cultura Galega, Santiago de Compostela.

Pires, H., Fonte, J., Gonçalves-Seco, L., Correia Santos, M. J., Sousa, O., 2014a. Morphological Residual Model. A Tool for Enhancing Epigraphic Readings of Highly Erosioned Surfaces, in: EAGLE- Information Technologies for Epigraphy and Cultural Heritage in the Ancient World. Sapienza Università Editrice, Rome, pp. 133-144.

Pires, H., Gonçalves-Seco, L., Fonte, J., Parcero-Oubiña, C., Fábrega-Álvarez, P., 2014b. Lidar-derived morphological relief models for the detection of archaeological features using mesh decimation. AARG Conference 2013, Amersfoort (The Netherlands). Poster presentation.

Pires, H., Martínez Rubio, J., Elorza Arana, J., 2015. Techniques for revealing 3D hidden archaeological features: Morphological Residual Models as Virtual-Polynomial texture Maps. The international Archives of the Photogrammetry, Remote Sensing and Spatial Information Sciences XL-5/W4, 415-421.

Pitcher, W. S., 1997. The Nature and Origin of Granite. Chapman \& Hall, London.

Plets, G., Verhoeven, G., Cheremisin, D., Plets, R., Bourgeois, J., Stichelbaut, B., Gheyle, W., De Reu, J., 2012. The deteriorating preservation of the Altai rock art: Assesing threedimensional image based modelling in rock art research and management. Rock Art Research 29 (2), 139-156.

Ramírez Sánchez, M., Guerra Soto, H., 2016. Hacia el corpus epigráfico de la Bética en 3D: una aproximación metodológica mediante Structure from Motion ( $\mathrm{SfM}$ ), in: Carbonell Manils, J., Gimeno Pascual, H. (Eds.), A Baete ad fluvium Anam: Cultura epigráfica en la Bética Occidental y territorios fronterizos. Homenaje al profesor José Luis Moralejo Álvarez. Universidad de Alcalá, Alcalá de Henares, pp. 361-379.

Ramírez Sánchez, M., Suárez Rivero, J. P., Castellano Hernández, M. A., 2014. Epigrafía digital: tecnología 3D de bajo coste para la digitalización de inscripciones y su acceso desde ordenadores y dispositivos móviles. El profesional de la Información 23 (5), 467474.

Ramírez Sánchez, M., García Sánchez, M., Giralt Soler, S., 2015. Epigraphia 3D. Un proyecto de innovación científica en la divulgación del patrimonio epigráfico de Hispania. Epigraphica. Periodico Internazionale di Epigrafia 77 (1-2), 371-396.

Remondino, F., 2014. Photogrammetry. Basic Theory, in: Remondino, F., Campana, S. (Eds.), 3D recording and modelling in Archaeology and Cultural Heritage. BAR International Series, Oxford, pp. 63-72.

Rivas, T., B. Prieto, O. Lantes, B. Silva., 2002. Grado de meteorización y formas de alteración de las rocas de construcción de megalitos gallegos. Nova Acta Científica Compostelana (Bioloxía) 12, 203-217. 
FINAL VERSION: Carrero-Pazos, M., Espinosa-Espinosa, D. 2018. Tailoring 3D modelling techniques for epigraphic texts restitution. Case studies in deteriorated roman inscriptions. Digital Applications in Archaeology and Cultural Heritage, vol 10. e00079 https://doi.org/10.1016/j.daach.2018.e00079

Rodríguez Colmenero, A., 1996. G. Baños Rodríguez, Corpus de Inscricións Romanas de Galicia, II. Provincia de Pontevedra, Consello da Cultura Galega, Santiago, 1994; 335 pp. Incluidas láminas, máis un mapa de dispersión dos epígrafes [recensión], Gallaecia 14$15,635-641$.

Rodríguez Lage, S., 1974. Las estelas funerarias de Galicia en la época romana. Instituto de Estudios Orensanos "Padre Feijoo", Ourense.

Seitz, S.M., B. Curless, J. Diebel, D. Scharstein, Szeliski, R., 2006. A comparison and evaluation of Multiview stereo reconstruction algorithms. Paper presented at 2006 IEEE Computer Society Conference on Computer Vision and Pattern Recognition.

Silva, B., 1992. A alteración do granito nos monumentos. Obradoiro. Revista de Arquitectura y Urbanismo 20, 94-96.

Ullman, S., 1979. Interpretation of Structure from Motion. Proceedings of the Royal Society of London Series B, Biological Sciences 203, 405-426.

Vallejo Ruiz, J. M. , 2016. III. Onomástica Paleohispánica. I Antroponimia y teonimia. 1. Testimonios epigráficos latinos, celtibéricos y lusitanos, y referencias literarias: Base de Datos Hesperia de lenguas paleohispánicas (BDHESP). Universidad del País Vasco, Bilbao.

Vergne, R., Pacanowski, R., Barla, P., Granier, X., Shlick, C., 2010. Radiance Scaling for Versatile Surface Enhancement, in: I3D '10 Proceedings of the 2010 ACM SIGGRAPH symposium on Interactive 3D Graphics and Games. ACM, New York, pp. 143-150.

Verhoeven, G., 2011. Taking computer vision aloft - archaeological three-dimensional reconstructions from aerial photographs with Photoscan. Archaeological Prospection 18, $67-73$.

Verhoeven, G., Taelman, D., Vermeulen, F., 2012. Computer vision-based orthophote mapping of complex archaeological sites: the ancient quarry of Pitaranhia (PortugalSpain). Archaeometry, doi/10.1111/j.1475-4754.2012.00667.

Vicente, M. A., Delgado Rodrígues, J., Acevedo, J. (Eds.), 1996. Degradation and conservation of granitic rocks in monuments: Proceedings of the EC workshop held in Santiago de Compostela (Spain) on 28-30 November 1994. Protection and Conservation of the European Cultural Heritage. Research Report 5, European Commission, Brussels.

Vilas-Estévez, B., Vázquez-Martínez, A., Carrero-Pazos, M., 2015. The Use of Photogrammetric Techniques for Recording the Rock Art Carving at Campo Lameiro (Galicia, Northern Spain), in: 43rd Computer Applications and Quantitative Methods in Archaeology "Keep the Revolution Going" Conference (CAA 2015 SIENA). Poster presentation.

Vilas-Estévez, B., Carrero-Pazos, M., Vázquez-Martínez, A., 2017. Going further: (Re)discovering rock art carvings with photogrammetric techniques in Galicia 
FINAL VERSION: Carrero-Pazos, M., Espinosa-Espinosa, D. 2018. Tailoring 3D modelling techniques for epigraphic texts restitution. Case studies in deteriorated roman inscriptions. Digital Applications in Archaeology and Cultural Heritage, vol 10. e00079 https://doi.org/10.1016/j.daach.2018.e00079

(Northwest Iberian Peninsula), in: Ippolito, A., Cigola, M. (Eds.), Handbook of Research on Emerging Technologies for Digital Preservation and Information Modelling. IGI Global, Hershey PA, USA, pp. 175-200.

Vives, J., 1971. Inscripciones Latinas de la España Romana (ILER). Antología de 6.800 textos. Universidad de Barcelona-Consejo Superior de Investigaciones Científicas, Barcelona.

Zambell, C. B., Adams, J. M., Gorring, M. L., Schwartzman, D.W., 2012. Effect of lichen colonization on chemical weathering of hornblende granite as estimated by aqueous elemental flux. Chemical Geology 291, 166-174. 

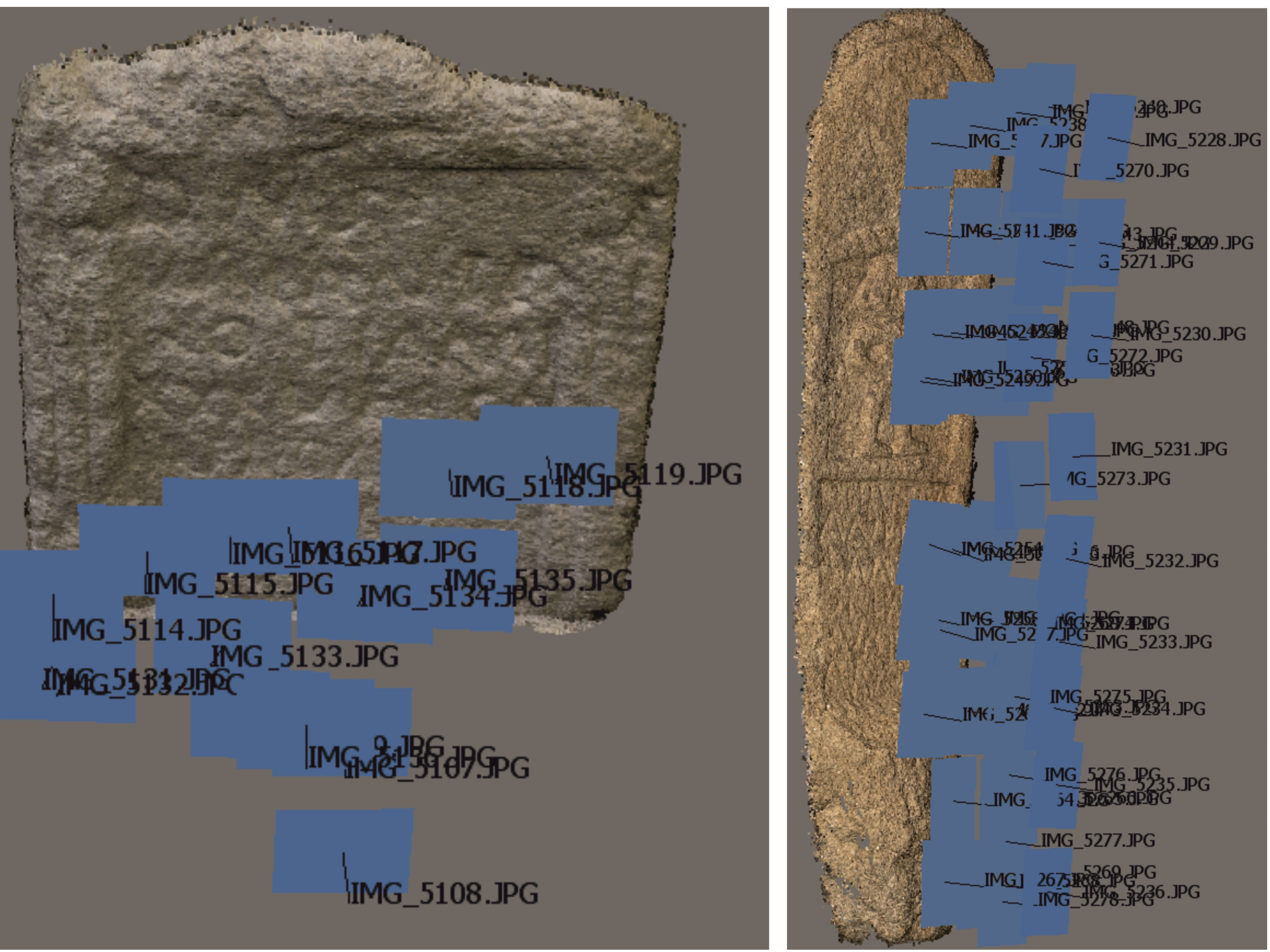


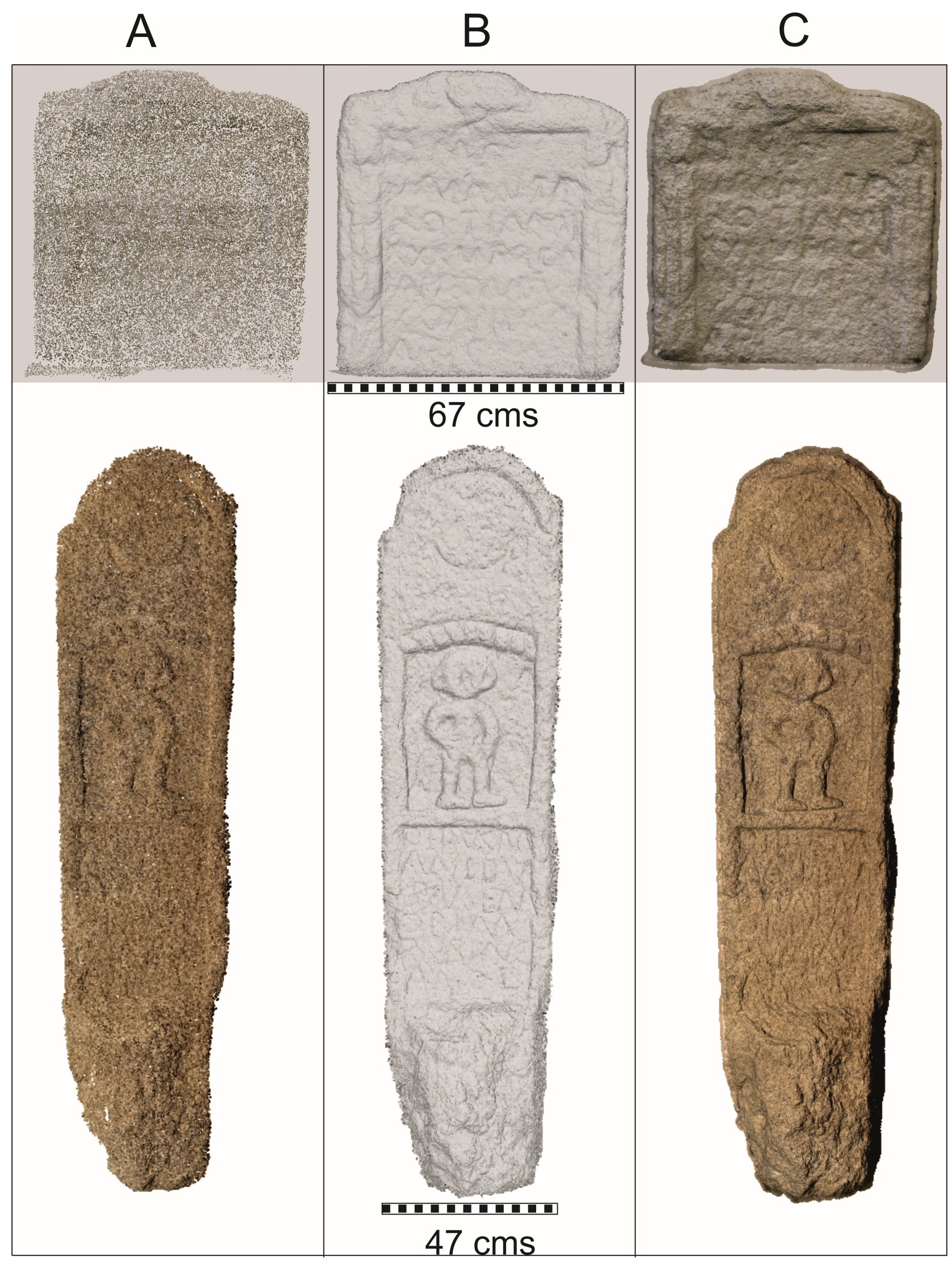


Camera: Cannon EOS 1200D

Resolution
Pixel size
F point
Exposition time
ISO Velocity
Exposure compensation
Focal length

\begin{tabular}{l} 
Dimensions \\
Resolution \\
Format \\
\hline Study case \\
Number of images \\
Resolution \\
\hline Tie-points \\
\hline Projections \\
Error \\
\hline Image overlap \\
3D model vertices \\
3D model faces \\
\hline
\end{tabular}

\begin{tabular}{|c|c|}
\hline \multicolumn{2}{|c|}{$5184 \times 3456$} \\
\hline \multicolumn{2}{|c|}{$4.4036 \times 4.4036 \mathrm{um}$} \\
\hline \multicolumn{2}{|c|}{$\mathrm{f} / 5$} \\
\hline \multicolumn{2}{|c|}{$1 \mathrm{~s}$} \\
\hline \multicolumn{2}{|c|}{ ISO-800 } \\
\hline \multicolumn{2}{|c|}{0 pass } \\
\hline \multicolumn{2}{|c|}{$33 \mathrm{~mm}$} \\
\hline \multicolumn{2}{|l|}{ Images } \\
\hline \multicolumn{2}{|c|}{$5184 \times 3456$} \\
\hline \multicolumn{2}{|c|}{72 ppp } \\
\hline \multicolumn{2}{|c|}{ JPG } \\
\hline \multicolumn{2}{|l|}{ model reconstruction } \\
\hline A Cidadela & Santa María de Cela \\
\hline 20 & 51 \\
\hline $0,00251683 \mathrm{~m} / \mathrm{pix}$ & 0,00265655 \\
\hline 74152 & 274509 \\
\hline 215965 & 744442 \\
\hline 0,377513 pix & 0,381065 \\
\hline$>9$ & $>9$ \\
\hline 404.313 & $2.245,188$ \\
\hline 806.709 & $4.483,961$ \\
\hline
\end{tabular}




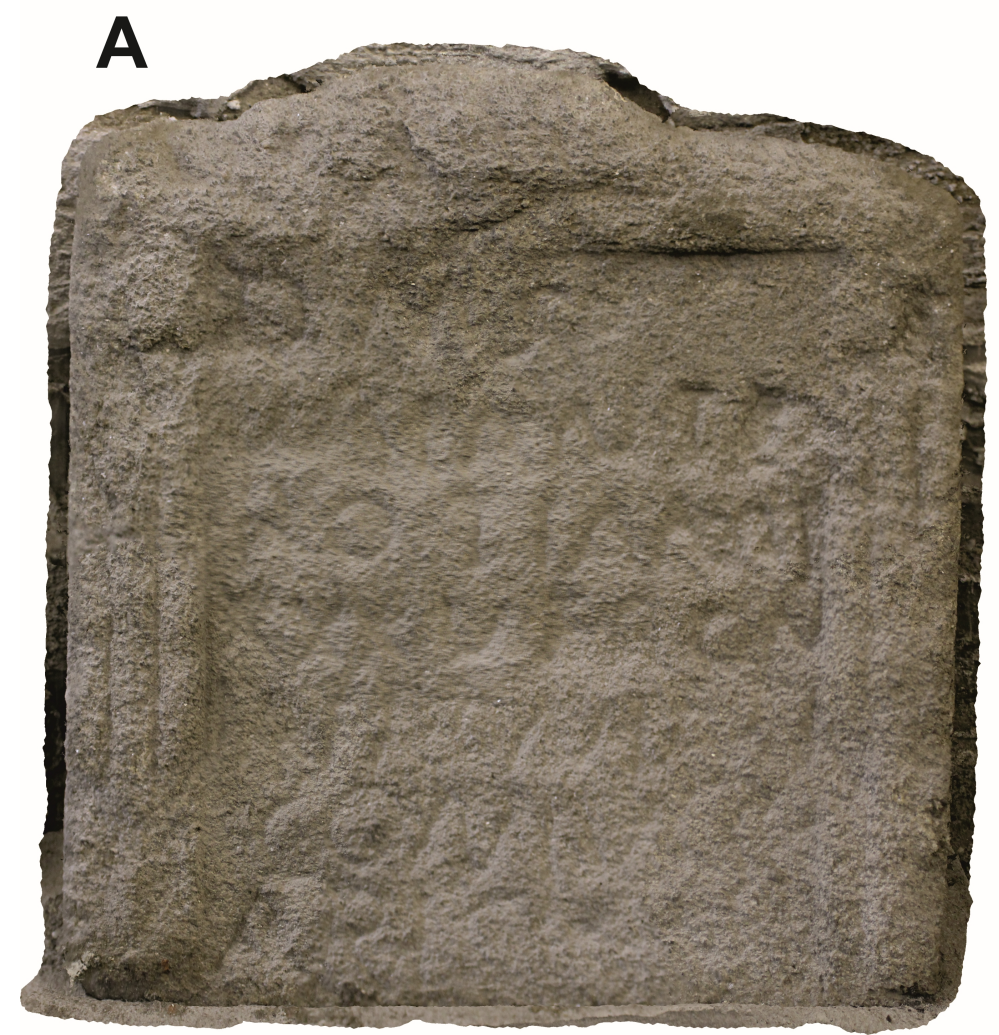

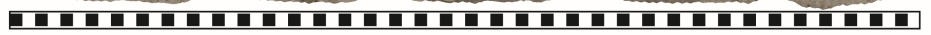
$67 \mathrm{cms}$

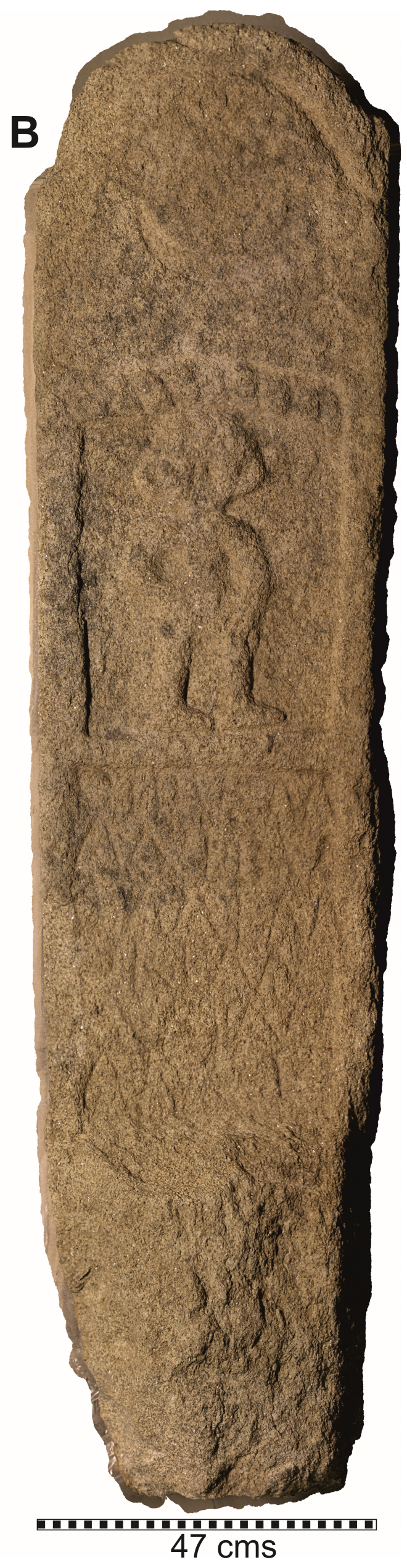




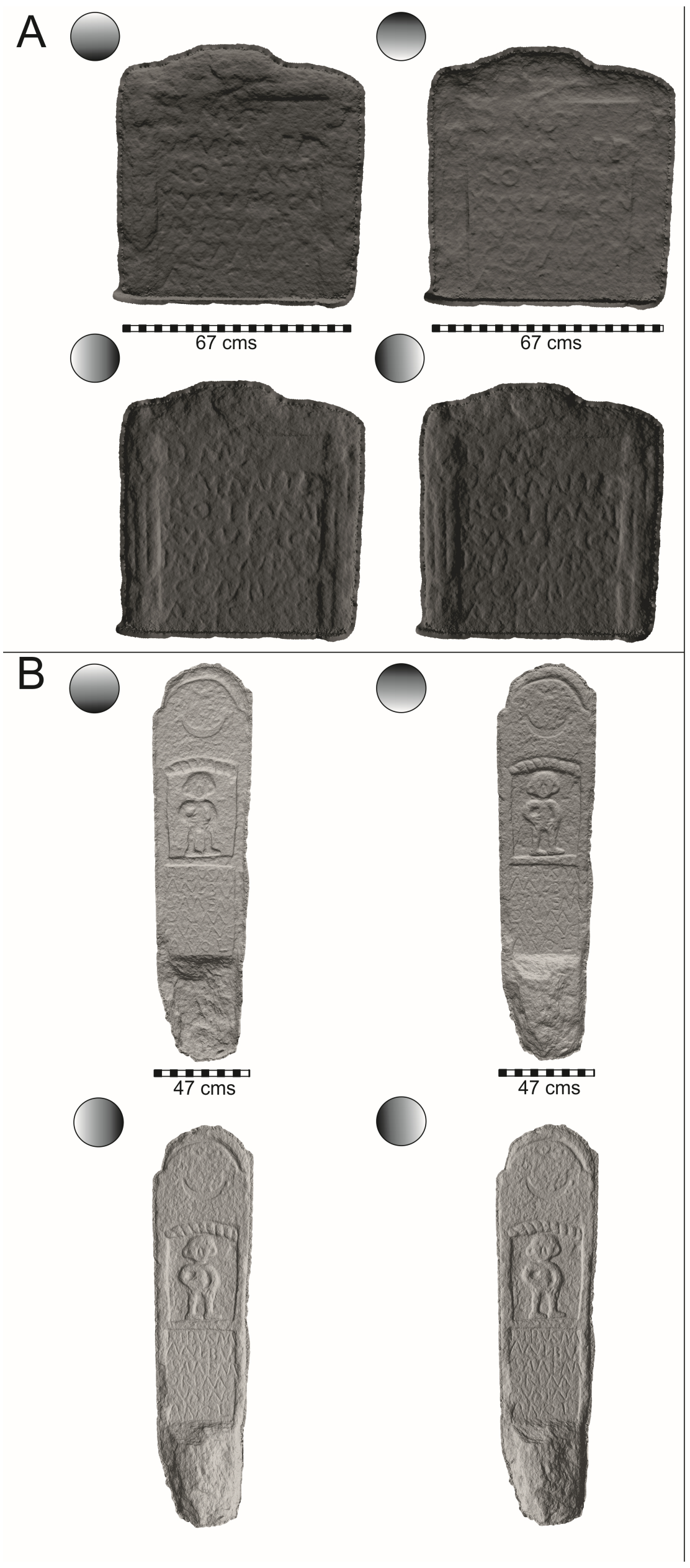




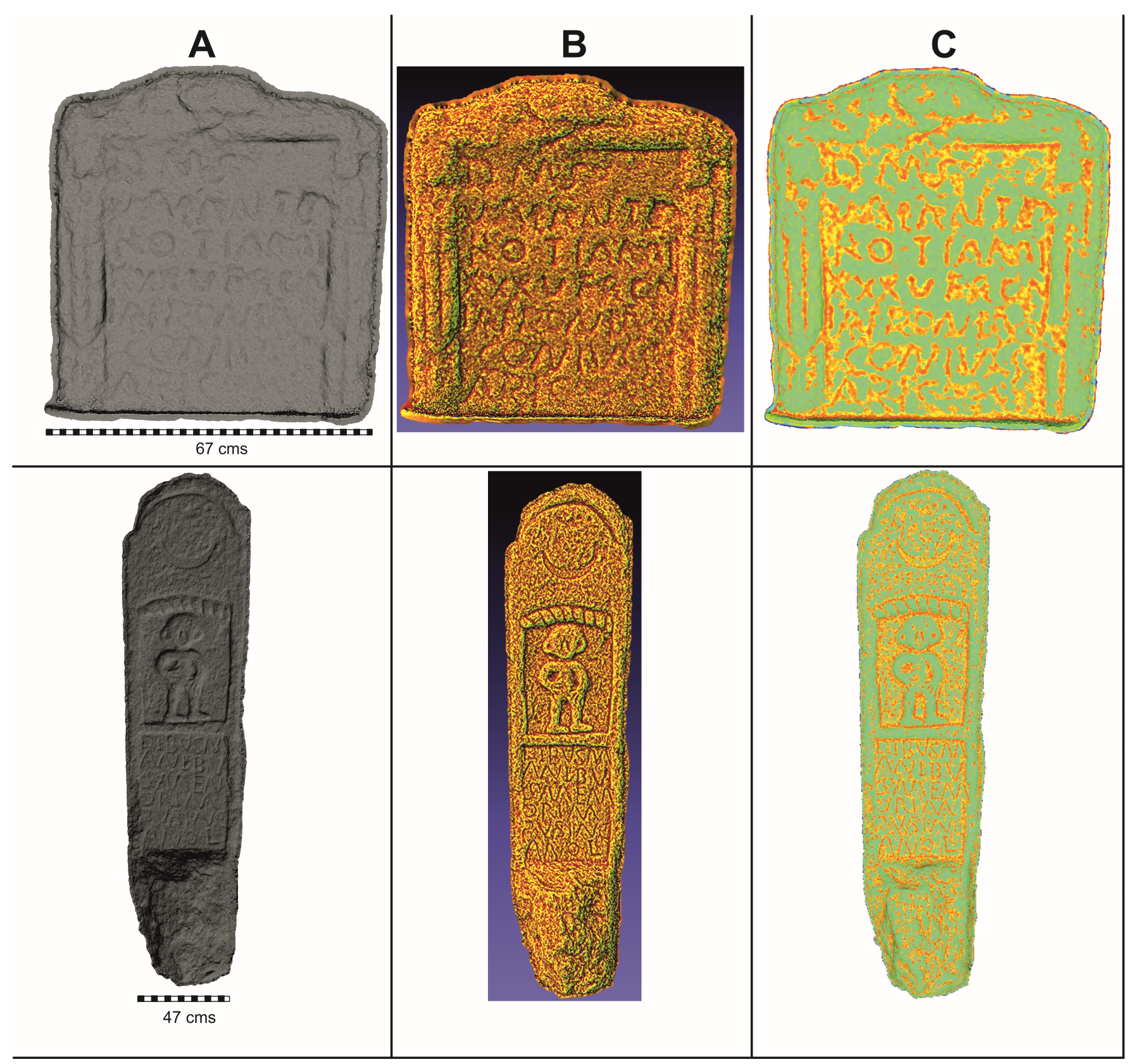




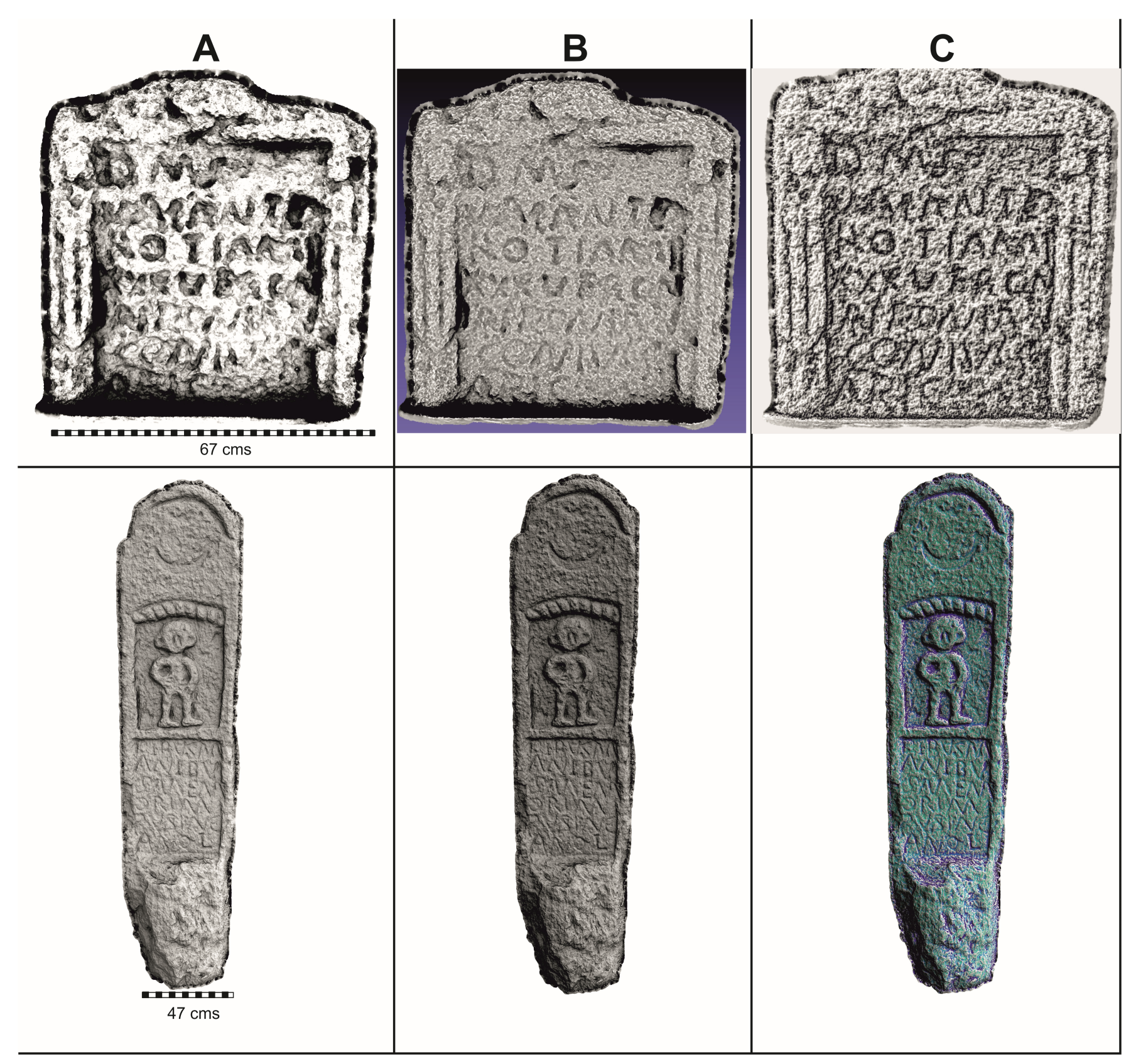





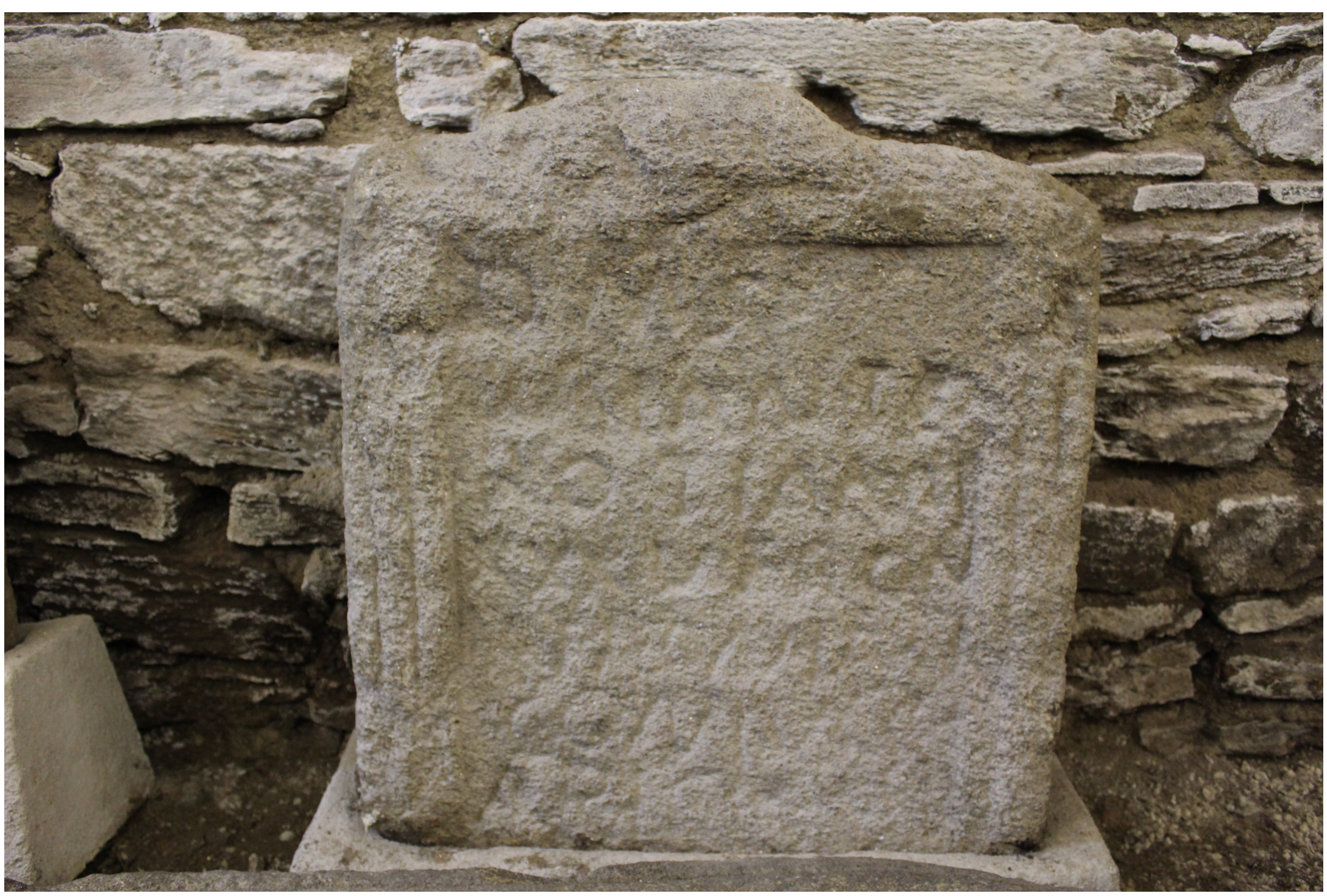




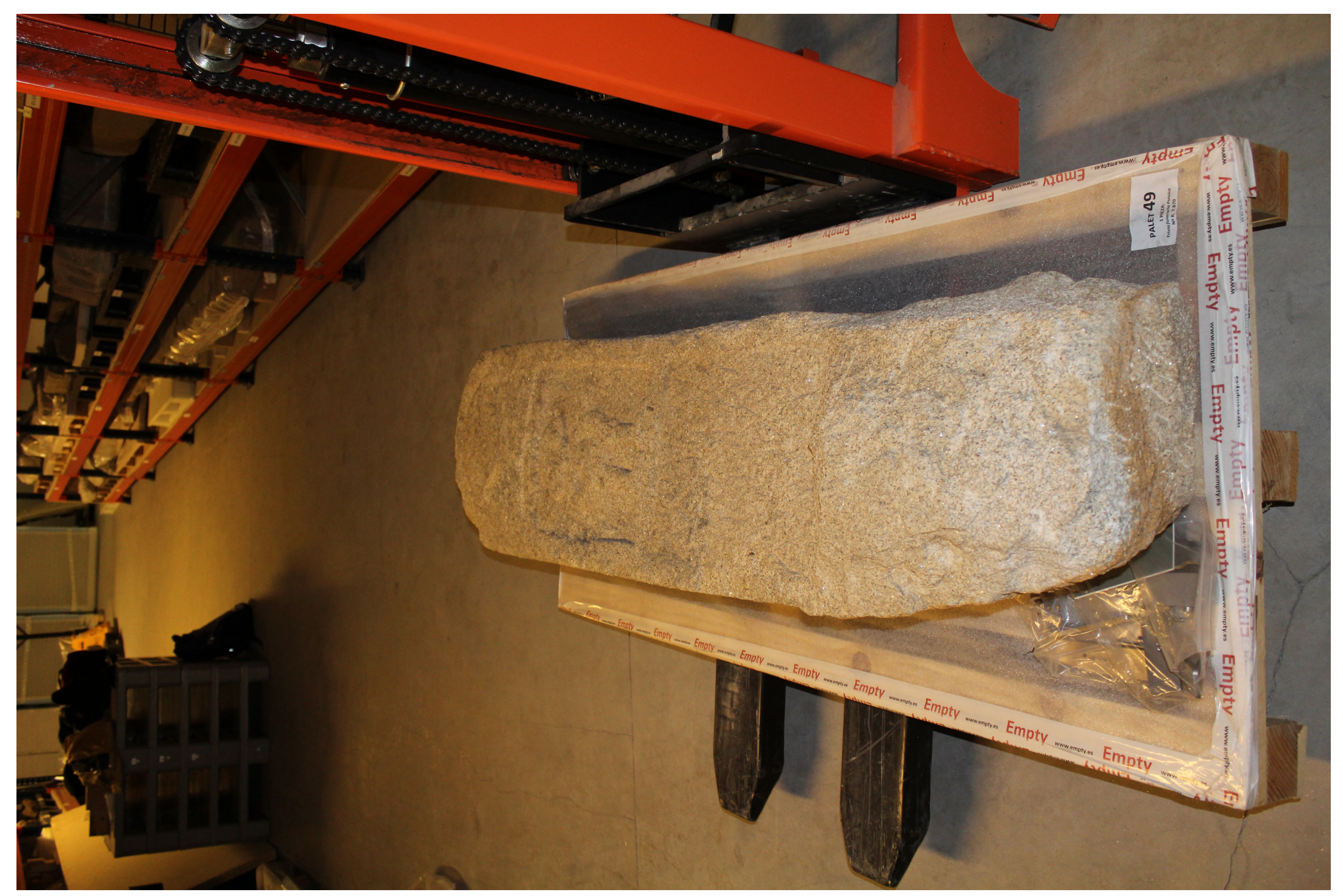





\begin{tabular}{|c|c|c|c|}
\hline \multicolumn{4}{|c|}{ MAIN READINGS } \\
\hline Author & Date & Epigraphic reading & $\begin{array}{c}\text { Bibliographic } \\
\text { reference }\end{array}$ \\
\hline $\begin{array}{l}\text { C. García } \\
\text { Romero }\end{array}$ & 1910 & $\begin{array}{l}\text { D(iis) M(anibus) S(acrum) / Valante / no } \\
\text { Tiami / XXXV Fron / ia Irenia / coniugi / } \\
\text { karissimo }\end{array}$ & $\begin{array}{c}\text { García Romero } \\
\text { 1910: } 263\end{array}$ \\
\hline F. Fita Colomé & $\begin{array}{r}1910 \\
-1911\end{array}$ & $\begin{array}{c}\mathrm{D} \text { (is) } \mathrm{M} \text { (anibus) s(acrum) / Um(midio) } \\
\text { Ante / roti ann(orum) / XXXV } \\
\text { fa(ciendum) cu(ravit) / I(ulia) Aproniana / } \\
\text { coniugi / carissimo }\end{array}$ & $\begin{array}{l}\text { Fita Colomé } \\
\text { 1910: } 360 \\
\text { 1911: } 405\end{array}$ \\
\hline $\begin{array}{l}\text { C. García } \\
\text { Romero }\end{array}$ & 1913 & $\begin{array}{l}\mathrm{D} \text { (iis) } \mathrm{M} \text { (anibus) S(acrum) / Val(erio) } \\
\text { Ante / ro Tiami (annorum) / XXXV Fron / } \\
\text { ia Irenia / coniug(i) / (k)aris(simo) }\end{array}$ & $\begin{array}{c}\text { García Romero } \\
\text { 1913: } 104\end{array}$ \\
\hline
\end{tabular}




\begin{tabular}{|c|c|c|}
\hline \multicolumn{3}{|r|}{ MINOR CHANGES } \\
\hline Part & New reading & Bibliographic reference \\
\hline \multirow{4}{*}{$\begin{array}{l}\text { Name of the } \\
\text { deceased }\end{array}$} & $\begin{array}{c}\text { Valentius } \\
\text { Tiami (filius) } \\
\end{array}$ & García Romero 1910: 263 \\
\hline & $\begin{array}{l}\text { Ummidius } \\
\text { Anteroti } \\
\text { (filius) }\end{array}$ & Fita Colomé 1910: 360, 1911: 405 \\
\hline & $\begin{array}{l}\text { Valerius } \\
\text { Anterus Tiami } \\
\text { (filius) }\end{array}$ & $\begin{array}{c}\text { García Romero 1913: 104; Bouza Brey, d'Ors 1949: } \\
\text { 44; Rodríguez Lage 1974: } 18\end{array}$ \\
\hline & $\begin{array}{l}\text { Valerius } \\
\text { Anteroti } \\
\text { (filius) }\end{array}$ & $\begin{array}{c}\text { Vives 1971: 434; Le Roux, Tranoy 1973: 223-224; } \\
\text { Pereira Menaut 1991: } 101\end{array}$ \\
\hline \multirow{4}{*}{$\begin{array}{l}\text { Dedicator } \\
\text { (deceased's } \\
\quad \text { wife) }\end{array}$} & Fronia Irenia & García Romero 1910: 263, 1913: 104 \\
\hline & $\begin{array}{c}\text { Iulia } \\
\text { Aproniana } \\
\end{array}$ & $\begin{array}{c}\text { Fita Colomé 1910: 360, 1911: 405; Pereira Menaut } \\
\text { 1991: } 101\end{array}$ \\
\hline & $\begin{array}{l}\text { Fronia } \\
\text { Froniani (filia) }\end{array}$ & $\begin{array}{c}\text { Bouza Brey, d'Ors 1949: 44; Vives 1971: 434; } \\
\text { Rodríguez Lage 1974: } 18\end{array}$ \\
\hline & Fronia Fronta & Le Roux, Tranoy 1973: 223-224 \\
\hline \multirow[t]{2}{*}{ Age of death } & 35 years & $\begin{array}{c}\text { García Romero 1910: 263, 1913: 104; Fita Colomé } \\
\text { 1910: 360, 1911: 405; Bouza Brey, d'Ors 1949: 44; } \\
\text { Vives 1971: 434; Le Roux, Tranoy 1973: 223-224; } \\
\text { Rodríguez Lage 1974: } 18\end{array}$ \\
\hline & 25 years & Pereira Menaut 1991: 101 \\
\hline
\end{tabular}




\begin{tabular}{|c|c|c|c|}
\hline \multicolumn{4}{|c|}{ MAIN READINGS } \\
\hline Author & Date & Epigraphic reading & $\begin{array}{l}\text { Bibliographic } \\
\text { reference }\end{array}$ \\
\hline $\begin{array}{l}\text { F. Fariña Busto and } \\
\text { A. García Alén }\end{array}$ & 1979 & $\begin{array}{c}\text { Dibus M / anibu / s mem / } \\
\text { oriâm / Pusin(na)e / } \\
\text { an(n)o(rum) L }\end{array}$ & $\begin{array}{l}\text { Fariña Busto, García } \\
\text { Alén 1979: } 318\end{array}$ \\
\hline G. Baños Rodríguez & 1994 & $\begin{array}{c}\text { Dibus M / anibu / s } \\
\text { mem / ori(a)m / Pusinc(ae) / } \\
\text { an(n)o(rum) L }\end{array}$ & $\begin{array}{c}\text { Baños Rodríguez } \\
\text { 1994:99 }\end{array}$ \\
\hline $\begin{array}{l}\text { A. Rodríguez } \\
\text { Colmenero }\end{array}$ & 1996 & $\begin{array}{l}\text { Dibus M / anibu / s mem / } \\
\text { orian (sic) / p(osuit) Ursine / } \\
\text { an(n)o(rum) L } \\
\text { Dibus M / anibu / s mem / } \\
\text { oriam / P(ublicius) Ursine / } \\
\text { an(n)o(rum) L }\end{array}$ & $\begin{array}{c}\text { Rodríguez Colmenero } \\
\text { 1996: } 637\end{array}$ \\
\hline $\begin{array}{c}\text { Hispania } \\
\text { Epigraphica }\end{array}$ & 2000 & $\begin{array}{c}\text { Dibus M / anibu / s mem / } \\
\text { ori(a)m / Pusinc(ae) } \cdot / \\
\text { an(n)orum L }\end{array}$ & HЕр 6, 2000: 709 \\
\hline
\end{tabular}


Figure 1. Granite inscriptions in poor state of preservation. A: Santa María do Viso, Redondela (CIRG II, 145). B: Funerary plaque of Ponte de Brandomil, Zas (CIRG I, 43).

Figure 2. The funerary plaque from A Cidadela, currently located at the Cathedral Museum in Santiago de Compostela.

Figure 3. The funerary stele from Santa María de Cela, currently stored at the Museum of Pontevedra.

Figure 4. Survey data: camera locations (Agisoft Photoscan Software).

Figure 5. Steps of 3D modelling. A: 3D spare point cloud. B: Meshed 3D model. C: Texturised 3D model.

Figure 6. Camera information and data characteristics of the photogrammetric study.

Figure 7. Ortho-images extracted from 3D model. A: Funerary plaque from A Cidadela. B: Funerary stele from Santa María de Cela.

Figure 8. Artificial light analysis of both inscriptions with different light angles. A: Funerary plaque of A Cidadela. B: Funerary stele from Santa María de Cela.

Figure 9. Stylistic stroke differences between both inscriptions.

Figure 10. Application of Radiance Scaling to both inscriptions. A: Lambertian Radiance Scaling. B: Radiance Scaling with red and yellow spheres. C: Comparison of meshes.

Figure 11. Ambient occlusion and colour mapping derivatives applied to both inscriptions. A: Ambient occlusion. B: Ambient occlusion plus Radiance Scaling Lambertian. C: Colour mapping through the mean curvature of the 3D model. 


\section{LIST OF TABLES}

Table 1. Main readings of the funerary plaque of A Cidadela.

Table 2. Minor changes on the different reading versions of the funerary plaque of $A$ Cidadela.

Table 3. Main readings of the funerary stele from Santa María de Cela. 